\title{
HISTORICAL THINKING AND REPRESENTATION IN CARYL PHILLIPS'S HIGHER GROUND AND J. M. COETZEE'S DUSKLANDS
}

\author{
Svetlana Stefanova Radoulska \\ Universidad Internacional de la Rioja \\ svetlana.stefanova@unir.net
}

\begin{abstract}
This study is an attempt to cross the boundaries between academic disciplines and provide a new perspective for the interpretation of the past in J. M. Coetzee's Dusklands (1974) and Caryl Phillips's Higher Ground (1989). The analysis of the narrative strategies the two authors share to expose patterns of socially and ideologically constructed representation of the historical «other» draws on some of the main ideas and concepts developed by Frank Ankersmit, one of the leading figures in contemporary historiography. Reflecting on the relation between interpretation, truth, and the meaning given to past reality, the present article reads the fragments of representations of the past as «narrative substances» and examines the choice and arrangement of these fragments in the two novels. The way individual stories of suffering are interconnected to stand as a «whole» helps our understanding of the discursive practices in the production of knowledge about the past and reveals their power and limitations.
\end{abstract}

Key words: F. Ankersmit, J. M. Coetzee, Caryl Phillips, narrative substance, representation.

\section{RESUMEN}

El presente estudio constituye un intento de cruzar los límites entre las disciplinas académicas y aportar una perspectiva novedosa a la interpretación del pasado en 
Dusklands (1974) de J. M. Coetzee y Higher Ground (1989) de Caryl Phillips. El análisis de las estrategias narrativas que comparten ambos autores para exponer patrones de representación construidos sociológica e ideológicamente del «otro» histórico se basa en algunas de las ideas y conceptos desarrollados por Frank Ankersmit, una de las figuras más relevantes dentro de la historiografía contemporánea. Reflexionando acerca de la relación entre interpretación, verdad, y el significado que se otorga a la realidad pasada, este artículo lee los fragmentos de las representaciones del pasado como «sustancias narrativas», examinando la elección y disposición de dichos fragmentos en las dos novelas analizadas. La manera en la que las se interconectan las historias individuales de sufrimiento para constituir un «todo» coadyuva a nuestro entendimiento de las prácticas discursivas en la producción del conocimiento acerca del pasado y revela su poder y sus limitaciones.

Palabras Clave: F. Ankersmit, J. M. Coetzee, Caryl Phillips, sustancia narrativa, representación.

\section{INTRODUCTION}

The last ten years have witnessed an increasing interest in the cultural, social and ideological use of narratives about the past. Historical consciousness has an important ideological and cultural function in the formation and transformation of individual and collective identity. Literary critics, philosophers, postcolonial and feminist theorists have examined our relationship to the past and have reflected critically on the nature and the production of knowledge with respect to history.

To explore the discursive strategies that reveal the power and the limits of historical representation I will draw on some ideas developed by the theorists of narrativism who analyze the similarities between historical writing and fiction with special attention to language used to account for the past. Some of them compare historiography to art in the sense that there is certain doubt about the capacity of the historical text to represent the past reality truthfully. Those theorists, who view the historical text as a narrative, discursively constructed and socially determined, share common concerns with postmodernist thinkers, who problematize and subvert metanarratives and universal assumptions and rethink historiography by exposing its mythmaking component. Linda Hutcheon claims that

History is not made obsolete: it is, however, being rethought -as a human construct. And in arguing that history does not exist except as text it [postmodernism] does not stupidly and 'gleefully' deny that the past existed, but only that its accessibility to us now is entirely conditioned by textuality (Hutcheon 1992: 16).

\section{THEORETICAL FRAMEWORK}

Hayden White's Metahistory: The Historical Imagination in Nineteenth-Century Europe (1973) marks a major shift in modern historiography. He examines the classics of nineteenth-century European historical thought as representative forms of historical reflection and offers a theory that points to the narrative dimension of historical discourse. He treats the historical work as «a verbal structure in the form of a narrative prose 
discourse» and believes that «the historian performs essentially poetic act, in which he prefigures the historical field and constitutes it as a domain upon which to bring to bear the specific theories he will use to explain 'what was really happening' in it». He goes on to establish four modalities in which the historian «prefigures» his account: Metaphor, Synecdoche, Metonymy, and Irony. Historians in a way constitute their object of analysis and are «indentured to a choice among contending interpretative strategies in any effort to reflect on history-in-general» (White 1987: IX-XII). Hayden White describes historical discourse as interpretation and historical interpretation as narrativization. His assumption that «history is accessible only by way of language and our experience of history is indissociable from our discourse about it» (White 1999: 1), provides the starting point of my comparative study of the narrative strategies used in J. M. Coetzee's Dusklands (1974) and Caryl Phillips's Higher Ground (1989) in order to unmask the way dominant discourse represents the oppressed «other» in different historical contexts.

Frank Ankersmit's Narrative Logic (1983) is considered together with Hayden White's Metahistory (1973) one of the most representative works of narrativist philosophy. He has discussed three main issues in his work: narration, narrative logic and, in particular, narrative substance, historical representation, and historical experience. As Aitor Bolaños de Miguel remarks, following Gombrich and Danto, Ankersmit claims that historical understanding takes the form of narration, and offers an aesthetic approach to historiography comparing historical to artistic representation (Bolaños de Miguel 2011: 277).

His interest in the historical text as a «whole» and in the exploration of the relationships between different texts representing the past is especially relevant to this study, as I will put together the «fragments of history» Coetzee and Phillips describe to analyze the result as a whole. Eugen Zeleňák, argues that a fundamental part of Ankersmit's theory is his Holism thesis, i.e. the idea that «A historical representation cannot be reduced to a mere sum of its statements» (Zeleňák 2009: 359-360). The order of these statements, the way they are assembled, is never innocent; it is the essence of representation. To evaluate a historical text we have to rely not only on the factual information but also on conceptual elements and the interaction between them. There are different representations of the same historical event, as Ankersmit shows, and it is not easy to decide on the one we prefer, because of the ambiguity inherent in the representation.

His theory of historical representation challenges the notion of historical writing as objective and neutral. According to Ankersmit, historical narratives are representations which contain not only a set of propositions that have a truth value but they also give a notion about the past reality and thus create meanings. The interpretation of the way data is assembled is what helps the understanding of the facts. He introduces the term «narrative substance» to present his three-level model of the relation between past reality and the text. The shift from the first level, that of the past in itself through the second, that of description, to the third -the level of representation-, is made possible by the existence of logical or linguistic units (narrative substances), which stand for a view of a fragment of the past and make historical narration.

By underlining the non-referential character of the narrative substances, he shows that narrative substances apply to the past but do not refer to it (Ankersmit 1994: 36), and claims that historical representation is a substitute for past reality. As we can only know the represented through representation, the latter takes priority over the former 
and can gradually substitute the represented. Ankersmit argues that «There is, thus, something peculiarly 'idealistic' about representation, in the sense that how we decide to conceptualize reality on the level of representation (of reality) determines what we will find on the level of the represented (i.e. on that of reality itself)» (Ankersmit 2001: 44).

Later, his interest shifts to historical experience by focusing on «how we experience the past and how this experience of the past may come into being by a movement comprising at the same time the discovery and a recovery of the past» (Ankersmit 2005: 9). First, we discover the past as «broken off» from the present, which is the moment of loss, and then by crossing the boundaries between past and present we recover the past, which is the moment of love. According to Ewa Domanska, Ankersmit «associates the concept of sublime experience with the concept of myth understood as suprahistorical and quasi-natural» (Domanska 2009: 184). His understanding of the «sublime» historical experience is closely related to his interest in truth in history.

In this line, in «Truth in History and Literature» he compares the role of narrative in both fiction and historical writing, suggesting that the latter can contribute to a better understanding of some variants of the novel. Instead of focusing on the literary dimension of historical narrative, he moves from history to novel «to find out about what can or should count as the novel's truth» (Ankersmit 2010: 30). Although the scope of his essay is restricted to the historical and realistic novel, this examination of the novel based on concepts belonging to the philosophy of history foregrounds the complex relation between truth and history in the novel and provides new tools for the analysis of the different strategies, applied to attribute a certain meaning to a historical event. Ankersmit reflects on the importance of the linguistic turn for historiography and humanities and establishes two levels to explain some misunderstandings of the issue of truth.

Firstly there is the (object-)level of (the) truth(s) about the world that are expressed in a text. Next, there is the (meta-)level of establishing either truthfully (or not, of course) which truth(s) the text actually expresses about the world and whether those truths are legitimate. ... [I]n complex literary texts questions of meaning and interpretation may drive questions of truth into the background; then it will be the second level that really matters (Ankersmit 2010: 32).

He proposes a metaphorical model of the relation between meaning and truth where the «horizontal axis» is that of language, meaning and interpretation, and the «vertical axis» is that of truth and the relationship between language and the world. He claims that if we assume that «interpretation involves not only the fixation of meaning but it also fixes a world» (Ankersmit 2010: 33), then it will be impossible to separate the vertical and horizontal axes from each other. He goes on to discuss truth in history attributing the function of representation to historical narrative and comparing it to paintings or portraits. For him there is a common ground between historical narrative and the historical novel in that both delineate aspects of the past and the difference is «formal rather than material and can be found in how historical truth is presented in each of them» (Ankersmit 2010: 44). An important difference between historical writing and the historical novel that is relevant for the present study is that the writer «shows» the past and the historian «says» what it has been like, he explains his choice of material and its interpretation in order to justify his narrative.

The comparative study of J. M. Coetzee's Dusklands (1974) and Caryl Phillips's Higher Ground (1989) constitutes an attempt to cross the boundaries between academic 
disciplines and provide a new perspective for the interpretation of the past. Through the examination of the strategies used to give meaning to the past the two authors contribute to the dissolution of common patterns of historical representation based on the dualistic approach «self»/«other». The two novels illustrate Ankesrmit's claim that we can only know the represented through representation. I will focus on the way they interpret the individual experience of the oppressed in order to inscribe this experience in our perception of the past. One of the narrative devices Phillips and Coetzee clearly share is fragmentation. Drawing on Ankersmit's theory of historical narration, I will read the textual fragments/stories/personal experiences that make the two novels as «narrative substances», and I will argue that the choice and the arrangement of these fragments if taken as a whole problematize the representation of the oppressed in different historical contexts.

\section{FRAGMENTATION}

Coetzee's Dusklands and Caryl Phillips's Higher Ground share a similar narrative structure, i.e. sections with no overt connection, set in different historical periods and places. In the fragments of past the reader can trace patterns of representation of the oppressed through history and reveal the creation and reproduction of master narratives. Recognizing that history is constructed and accessible discursively, the fragmented structure of the two novels creates a new awareness not only of the subjectivity of historical discourse but also of the need of putting into discourse the viewpoints of those who have been marginalized and silenced. I will read these fragments of the past as narrative substances and, following Ankersmit's argument that it is necessary to explore the relationship between the different texts in order to comprehend the whole, I will examine the common ground for the joining of these fragments.

Dusklands is made up of two novellas: «The Vietnam Project» and «The Narrative of Jacobus Coetzee». The first part shows Eugene Dawn, who is appointed by the administration to write a report on the efficiency of broadcast propaganda as a military strategy in the war against Vietcong in the 1960s and 1970s. The second part, «The Narrative of Jacobus Coetzee», takes place in South Africa in the eighteenth century and is the story of a Dutch colonizer and his encounters with the «other». The intertextual dialogue between the two parts questions the ground on which historical writing claims to represent the truth about the past. The two parts do not have a plot connection but the reader, like in Caryl Phillips's Higher Ground, is challenged to discover parallels in the representation of the colonized «other» by the power discourse and unmask the meaning given to this representation.

Phillips's Higher Ground has a similar structure: three sections with complex thematic connections between otherwise disparate characters. The first part, «Heartland», is the story of a slave who works as an interpreter in a British trading fort in the late eighteenth century. «The Cargo Rap» features Rudy, a young black American detained in prison for robbery in the 1960s and is based on the correspondence with his parents, sister, and attorney. The third section, «Higher Ground», is the story of a Jewish refugee from Poland, who is sent by her parents to England to escape from the Nazis. The three juxtaposed texts are located in three continents: Africa, America, and Europe, and what 
joins them together is the fact that all of them are inscribed in historical periods known for phenomena of massive displacement, dispossession, and racial hostility. Each of the sections contains a representation of the oppressed and each personal experience of suffering subverts this representation. For Phillips historical writing with its presumably realistic discourse is unable to represent extreme historical events, such as slavery or the Holocaust, that can only be reached through personal accounts of the victims.

By choosing to combine fragments of text referring to different historical periods, Phillips and Coetzee decontextualize them to show that both history and fiction are constructs and that our perception of the past depends on the way historians and novelists assemble and interpret these representations of past events.

\section{NARRATIVE VOICES}

The two authors subvert the universality of the dominant discourse and its representational power, though in a different way. Caryl Phillips contests the historians' claim to truthful account of reality by showing that documents and records of past events provide knowledge of only a small portion of reality, and opts for multiplicity of perspectives in an attempt to rethink history and include the account of those previously silenced. Coetzee chooses a different strategy to achieve the same purpose, to prove the dominant representation of the oppressed unreliable. His two narrators Eugene Dawn and Jacobus Coetzee speak on behalf of the colonial power, and their representation of the racialized «other» follows and supports the stereotypes established by the oppressors to justify their violence and aggression.

By unifying the two narrative voices, Coetzee asks us to look at them as one, as the voice of the totalizing narrative that represents historical events from the perspective of certain ideology which predetermines the unreliability of the text as a truthful reflection of reality. The author of Dusklands deliberately establishes the name «Coetzee» as a cross-text reference not only between the first and the second part of the novel but also between the different fragments of the second part. In the first part, the editor of the Vietnam Project is called Coetzee and he represents the authority over Eugene Dawn. The second part, «The Narrative of Jacobus Coetzee», is told by Jacobus Coetzee, translated by J. M. Coetzee, and «edited with an afterword by S. J. Coetzee». Susan Gallagher argues that «In posing as the 'editor' of The Vietnam Project and the 'translator' of The Narrative of Jacobus Coetzee, Coetzee exposes his own role as the constructor of discourse» (Gallagher 1991: 73). The author's explicit reference to the name Coetzee emphasizes his main concern with the relation between authorship and history. Acknowledging the constructedness of the representation of two acts of aggression, the Vietnam war and the colonization of South Africa, shifts our perspective of reading as we become gradually aware of the process of creation of this representation.

Eugene Dawn, who is in charge of analyzing the effects of propaganda in the Vietnam war, works in the Mythology section. In his recommendations on the project, Eugene's manager, Coetzee instructs him to write «some kind of introduction in which to explain in words of one syllable the kind of procedure [he] follow[s] - how myths operate in human society, how signs are exchanged, and so forth» (Coetzee 1983: 4). 
Coetzee exposes the producer of the narrative as a mythmaker and reveals his discursive practices. In his study of Coetzee's first six narratives David Atwell argues that «Coetzee's novels are located in the nexus of history and text; that is, they explore the tension between these two polarities» (Attwell 1993: 2-3).

Another link between the narrator of «The Vietnam Project» and the narrator of «The Narrative of Jacobus Coetzee» is the similar representation of the two male characters. The author shows their lack of authority in representing the «other» as an embodied subject by describing their weak and sick bodies. The recurrent images of ugly, naked, helpless bodies in pain are associated with the racialized «other». However, the author opposes the assumption that the «other» should be identified and represented by his/her body by showing that when stripped of their power attributes, i.e. the pen and the gun, the two oppressors, Eugene Dawn and Jacobus Coetzee, become two helpless, nameless bodies in pain. It is interesting to mention here Ankersmit's idea about the characters in the historical novel. For him, «whereas a historical narrative aims at the construction of some representation of part of the past, the historical novel applies the historical knowledge conveyed by a representation of the past to the historical novel's main characters» (Ankersmit 2010: 45). He claims that characters are typically «flat, uninteresting and of no historical significance themselves». In emphasizing their role as mythmakers, but at the same time presenting them as insignificant, uninteresting characters whose only development in the novel is their becoming extremely violent at the end of the stories, Coetzee shows the limitations of power discourse in describing the past.

Caryl Phillips adopts a different approach. Like a historian who constructs his narrative with different representations of the same past event, chosen and assembled to delineate a certain aspect of the history, Phillips focuses on three stories describing three personal experiences of extreme suffering as a result of violence based on racial discrimination. Witnesses' testimonies have always been essential for historians. In the early 1990s an area of cultural studies called «trauma studies» became prominent. Trauma studies theorists explore accounts of traumatic experiences as a way to gain access to historical events otherwise unrepresentable because of their extreme violence. Stef Craps offers an in-depth analysis of Higher Ground from this perspective. He argues that «Phillips does not treat these individual histories in isolation but lets them address one another» (Craps 2012: 157), and focuses on Phillips's management of empathy as a unifying element. The ways in which the three parts interconnect give meaning and help to increase our understanding of the texts.

The interpretation of Phillips's strategy is closely related to the choice of names for his characters. The first narrator is a nameless African interpreter whose only tool for survival is the knowledge of the colonizer's language. "In 'The Cargo Rap' it is no longer the absence of a name, but rather its multiple forms that are significant, because they testify to the narrator's alienation» (Ledent 2002: 58). His full name is Rudolph Leroy Williams, but he is referred to simply as «Rudy», suggesting or implying «rude» or «rudeness» as a common feature of the stereotyped representation of black people in the United States in that period. Rudy's personal experience in prison and his reflections on power in history take the form of letters to his family. These short texts, similar to diary entries, remind us of the intimate confessions of a victim. While setting the ground for sympathizing with the character, Rudy's letters, charged with political, historical, and 
philosophical references, lay bare the subjectivity of his narrative. The last part, «Higher Ground», is told in the third person, and the main character, a traumatized young Jewish woman, is referred to as Irene or Irina throughout the story. Irene's nightmarish experiences of suffering and loneliness are integrated in the common space shared by those subject to violent oppression.

\section{STEREOTYPES AND MEANING}

In Ankersmit's view, we can know the represented only through representation, and the latter can gradually substitute the former. After examining the construction of the representation of the historical «other» as exposed by the two authors, I will focus on examples of stereotyped representations of the oppressed in terms of the binary opposition «us»/«them» as the key to understanding the social and ideological meaning given to these representations. Coetzee and Phillips's inquiry into the discursive practices that represent the «other» as inherently inferior takes as a starting point the idea that the «other» has traditionally been identified with the body, and the dominant subject, identified with mind and reason, is endowed with the power to write history and give meaning to the past.

The suffering body, perceived as a surface with marks read as traces of the past, has a particular relevance in analyzing Coetzee's interest in the representation of the racialized «other». For Coetzee the utmost expression of authority and suppression of identity is the attack against human dignity, and as such he describes rape as absolute domination. He shows its use as a weapon in the Vietnam war and in the colonization of new territories in the second part of Dusklands. For Rosemary Jolly, Dusklands «makes clear the link between the erasure of otherness, rape, and the fantasy of mastery» (Jolly 2009: 94). In «The Narrative of Jacobus Coetzee», the author brings together two stereotyped representations: that of a Dutch girl and a Bushman girl. The Dutch girl is reduced to the property she owns and the Bushman girl is described as a powerless embodied object to be dominated and possessed by the white colonizer. Once the men that represent power to her are dead, her body becomes an epitome of abandonment and pain: «She has seen you kill the men that represented power to her, she has seen them shot down like dogs. You have become power itself now and she nothing, a rag you wipe yourself on and throw away» (Coetzee 1983: 61).

There exists a clear parallel between the description of the Bushman girl and the description of the African girl from Phillips's «Heartland». The Military chief of the fort, Price, accompanied by the interpreter, travels to the nearest village, where he chooses a sixteen-year-old girl for his «temporary personal use». After repeatedly violating and torturing the girl until her «spirit seems to have been drained from her» (Phillips 2006: 42), Price decides that he has «no further use for her» (Phillips 2006: 33), and sends her covered in blisters and burn marks back to her home village, where she is rejected and abandoned by her family, because she is considered impure. For the interpreter, his relation with the girl is an opportunity to gain knowledge of himself and to regain his manliness. However, when the girl is raped again, this time by a soldier, his first reaction is similar to her father's reaction, i.e. he rejects the girl. In the third part 
of Phillips's novel it is the image of Irene's traumatized mind and body that bears the traces of humiliation and violence. Her childhood memories hint at a troubled relation with her father. Frustrated and lonely in England, she desperately tries to break her isolation and build a life through her relation with Reg. Unfortunately, the unbearable sequence of traumas from losing her family and domestic violence to losing her child leads her to an attempt to commit suicide. Her increasing isolation reveals a series of traumas that slowly erode her emotional faculties until she suffers a nervous breakdown and has to be confined to a mental hostpital. As Phillips and Coetzee demonstrate, rape as an act of conquering and domination relates to the representation of the historical «other» as an embodied subject.

Another stereotype, often used to justify aggression and perpetuate patterns of oppression, is the representation of the racialized «other» as a potentially dangerous savage. To unmask the ideological construct behind this representation, in Giving Offense. Essays on Censorship Coetzee reflects on the process of creating stereotypes:

When Europeans first arrived in southern Africa, they called themselves Christians and the indigenous people wild or heathen. The dyad Christian/heathen later mutated, taking a succession of forms, among them civilized/primitive, European/native, white/non-white. But in each case, no matter what the nominally opposed terms, there was a constant feature: it was always the Christian (or white or European or civilized person) in whose power it lay to apply the names - the name for himself, the name for the other» (Coetzee 1996: 1-2).

«Giving name» in the sense of attributing certain qualities in the process of creating identity is, as the author of Dusklands points out, a prerogative of power. If in the belief of the white colonizer Christianity stands for civilization, then religion symbolizes «the gulf that divides» Jacobus from the Hottentots. Jacobus also compares the Hottentots and the Bushmen to wild animals, one of the stereotypes in the eighteenth century travel narrative, categorizing the local inhabitants as inferior by nature. He attempts to take the role of a noble hunter while the indigenous people are represented as creatures without history or culture, beasts «with animal's soul» and deviant behavior. The disregard he shows when he describes the torture and killing of several Bushmen is similar to Eugene's depiction of the raids on the Vietnamese homes and villages. «A bullet is too good for a Bushman. They took one alive once after a herder had been killed and tied him over a fire and roasted him. They even basted him in his own fat» (Coetzee 1983: 60).

The encounter and the relations self/other in distinct forms of colonization are characterized by the representation of the colonized as childish and naïve. The colonizer attributes to himself permissibility and authority, supported by the idea of cultural supremacy over the «other». In the line of these ideological representations of the past, the concept of the «father figure» holds a special place in Coetzee's Duskland. In the first part, «The Vietnam Project», Eugene discusses the importance of the «father-voice» for the achievement of the «totalitarian purposes» of the aggressor. Asked by his manager to explain «how myths operate in human society», Eugene writes an introduction to the project, divided in several numbered sections starting with the «Aims of the report» and the «Aims and achievement of propaganda services», and ending with a paragraph called 
«Victory». The main part of this introduction is devoted to the «father-voice» as a source of propaganda. Eugene writes:

The voice of the father utters itself appropriately out of the sky. The Vietnamese call it 'the whispering death' when it speaks from the B-52's, but there is no reason why it should not ride the radio waves with equal devastation. The father is authority, infallibility. He does not persuade, he commands. That which he foretells happens (Coetzee 1983: 21).

The racialized «other» is represented as a subordinate subject to be patronized and punished if necessary. The omnipotent figure of the father stands for domination, but also for paternal love. When he decides to punish his child, the punishment is administered for the good of the child and is supposed to be «fair». The father figure is also viewed as a protector, a master caring for his servants and slaves. In the second part of Dusklands, Jacobus Coetzee reflects on his rightful authority over his servants, convinced that they could not have survived the journey without his paternal protection: «It was I who saw that every man had food . . . It was I who . . . restored order with a firm but fair hand. They saw me as their father. They would have died without me» (Coetzee 1983: 64). The analysis of the relation between doctrines, truths, and imperial discourse about the past in Higher Ground and Dusklands, confirms Ankersmit's assumption that «interpretation involves not only the fixation of the meaning but also of a world», and that «meaning will determine the truth in the sense of entailing its own truth-conditions» (Ankersmit 2010: 33).

\section{DOCUMENTARY NARRATIVE}

An interesting narrative strategy that Phillips and Coetzee share is the mixture or juxtaposition of documentary and fictional narrative which reveals the complex relations between factual and conceptual elements in representing the past. They explicitly undermine the traditional assumption that history is able to represent past reality through accurately recorded and selected facts. By placing historical and fictional narrative together, the two authors show that, as Ankersmit points out, there are different representations of the same historical event, and, although the «statements» as individual constituents of the historical representation describe reality, the facts are not enough to understand the past; we rely on our understanding of the viewpoint of the historian and also on our own viewpoint in order to assess the truthfulness of a particular representation.

In the first part of Higher Ground, «Heartland», Caryl Phillips tells the story of a black interpreter in a military fort, where black people are «stored» after being captured from the nearby villages before being sent to the plantations in America. To describe these regular inland raids, Phillips relies on the writings of Ignatius Sancho and the autobiography of Olaudah Equiano. In Equiano's narrative about his life in slavery the reader can find a detailed description of the raids:

One day, when all our people were gone out to their works as usual, and only I and my sister were left to mind the house, two men and a woman got over the walls, and in a moment seized us both, and without giving us time to cry out, or make resistance, they stopped our mouths, and ran off with us into the nearest wood (Equiano 2002: 62). 
The representation of the narrator's public humiliation at his arrival at the fort when he is forced to drink alcohol, dance, and sing to entertain the soldiers, is also based on Equiano's memories. Both genres rely on documents and accounts about historical events, and both texts, Equiano's and Phillips's, are discursive constructs of the past. If Equiano's memories and Ignatius Sancho's letters are sources of information about African slavery for historians, but also for novelists then «there appears to be much more common ground between history and novel than immediately meets the eye» (Ankersmit 2010: 43). In the second part, «The Cargo Rap», Phillips adopts a different approach to the mixture of facts, personal experience, and the representation of the racialized «other», i.e. he relies on intertextuality. In a letter to his sister the main character, Rudy, includes the story of Phillis Wheatly, who was taught to read and write by the family who owned her as a slave, then started publishing poetry and became internationally known. He emphasizes the fact that she was soon abandoned not only by her husband but also by the white society who admired her work to demonstrate that patterns of racial oppression are repeated through history. The overabundance of references to philosophers, politicians, and writers like Mao, Marx, Frantz Fanon, and R. Wright, to mention but a few (i.e. the overabundance of factual elements), does not fill in the gaps of our understanding of Rudy's experience, but rather alienates the reader from his account.

Coetzee applies a similar narrative strategy in the two parts of Dusklands. He juxtaposes the narrative of Eugene Dawn and Jacobus Coetzee to texts that refer to the same historical events, but contain plenty of facts and figures. In the first part the documentary narrative juxtaposed to Eugene's personal account is the «Introduction to the Vietnam Project» and, in the second, the Afterword and the Apendix, which presumably historical narratives, are compared with Jacobus' account of his journey into the «heart of darkness». In «The Vietnam Project», the author first exposes the process of creating a documentary narrative by an ideologically biased mythmaker which undermines the credibility of the document that follows: «New Life for Vietnam». The latter is written in a style resembling a document with numbered paragraphs, headings, data, and even a formula to calculate the probability of success when the US army strikes a target is included. Although Eugene tries to look as a mere observer, objectively analyzing the facts, he gets emotionally involved in the defence of violence. The relation between language and truth in the myth-making, used for propaganda, becomes clear when Eugene admits that they «have justified the elimination of enemy villages by calling them strongholds» (Coetzee 1983: 20). In this line, Sue Kossew argues that «Language itself is therefore implicated in the process of aggression and, indeed, becomes a vital tool for the aggressors in their self-justifying myths, which provide a distorted view of reality.» (Kossew 1996: 38). It is interesting to examine Coetzee's choice to represent the extreme war violence through the descriptions of some pictures, attached to the Vietnam Project. Pictures are traditionally considered a powerful historical document and many war zone live reports rely heavily on images. They have a strong impact on the audience because they are perceived as a truthful reflection of reality. To emphasize the idea that past reality can only be reached through narrative, Coetzee gives the reader access to the photographs through Eugene's description, who speaks on behalf of the aggressor. The description starts with sergeant Loman's height, weight, and other factual information, then describes him «copulating with a Vietnamese woman», and ends giving a title to the picture: «Father Makes Merry with Children» (Coetzee 1983: 13), i.e. he gives meaning to the facts 
described before. Coetzee's mode of representing war reality suggests the fictionality of history and relates to his idea of the narrator as a mythmaker. Patricia Waugh takes a special interest in the exposure of reality as a construct as one of the characteristics of metafiction:

«Reality» is manufactured. It is produced by the interrelationship of apparently «objective facticities» in the world with social convention and personal and interpersonal vision. These social forms operate within particular historical structures of power and frameworks of knowledge. Continual shifts in the structures of knowledge and power produce continual resyntheses of the reality model. . . . It is no longer experienced as an ordered and fixed hierarchy, but as a web of interrelating, multiple realities (Waugh 1984: 51).

In the second part of Dusklands, Jacobus Coetzee's narrative about his journey is followed by an Afterword and an Appendix, written in the style of a historical narrative. By apparently claiming historical veracity and confirming Jacobus' narrative, these different representations of the same event blur the boundary between history and fiction and reveal the mechanism of ideologically constructed justification of oppressive practice.

\section{CONCLUSION}

The analysis of the textual strategies at work in Coetzee's Dusklands and Phillips's Higher Ground demonstrates the authors' commitment to expose the ideological constructedness of the representation of the oppressed in history. I have limited myself to a few narrative techniques that both authors adopt and that make particularly evident some of the main ideas developed by Frank Ankermit. The analysis shows that Coetzee and Phillips challenge the traditional notion of linear time in historical writing by choosing and assembling fragments of the past without explicit connection between them. By alluding to records of extreme violence towards the historical «other» in periods marked by imperial expansion and aggression, a complex web of parallels is created not only within the structure of each novel, but also between the two novels. Putting the fragments together and viewing the representation of the oppressed as a whole reveal a discursive practice repeated in all the historical contexts chosen by the authors. Thus, personal experiences transcend the individual accounts and help us to understand the meaning given to this representation by the dominant discourse. The discrepancies between the different representations of the same historical event undermine the credibility of the dominant narrative and foreground the conflict between representation and truth. Coetzee and Phillips insist on the idea that documents recording past events are not enough to interpret and understand history. Assuming that the past is accessible only through narrative, and at the same time reflecting on the creation of myths based on stereotypes, they question the possibility of historical representation to reflect the past objectively. Following Ankersmit's metaphorical model of the relationship between meaning and truth, it becomes clear that our perception of past reality is conditioned by its representation and by the perspective from which a certain meaning is given to this representation. 


\section{WORKS CITED}

Ankersmit, F. R. (1994). History and Tropology. The Rise and Fall of Metaphor. Berkeley: University of California Press.

- (2001). Historical Representation. Stanford: Stanford University Press.

- (2005). Sublime Historical Experience. Stanford: Stanford University Press.

- (2010). «Truth in History and Literature». Narrative 18.1. (January: 29-50).

Attwell, David (1993). J. M. Coetzee. South Africa and the Politics of Writing. Berkeley and Los Angeles: University of California Press.

Bolaños De Miguel, A.M. (2011). «Historiografía y postmodernidad: la teoría de la representación de F.R. Ankersmit». Historia y Política 25 (271-308).

Domanska, Ewa (2009). «Frank Ankersmit: From Narrative to Experience». Rethinking History 13.2 (June: 175-195).

Coetzee, J. M. (1983). Dusklands. London: Penguin Books, 1974.

- (1996). Giving Offense. Essays on Censorship. Chicago: The University of Chicago Press.

Craps, Stef (2012). «Linking Legacies of Loss», in Ledent, Bénédicte and Daria Tunca (eds.) Caryl Phillips. Writing in the Key of Life. Amsterdam and New York: Rodopi.

Gallagher, Susan Van Zanten (1991). A Story of South Africa. J. M. Coetzee's Fiction in Context. Cambridge \& Massachusetts: Harvard University Press.

Hutcheon, Linda (1992). The Politics of Postmodernism. London and New York: Routledge

ICKE, Peter P. (2010). «Frank Ankersmit's Narrative Substance: A Legacy to Historians. Rethinking History. 14.4 (December: 551-567).

Jolly, Rosemary J. (1996). Colonization, Violence, and Narration in White South African Writing: André Brink, Breyten Breytenbach, and J. M. Coetzee. Ohio: Ohio University Press.

Kossew, Sue (1996). Pen and Power. A Post-Colonial Reading of J. M. Coetzee and André Brink. Amsterdam: Rodopi.

Ledent, Bénédicte (2002). Caryl Phillips. Manchester and New York: Manchester University Press.

Phillips, Caryl (2006). Higher Ground. London: Vintage Books, 1989.

White, Hayden (1987). Metahistory: The Historical Imagination in Nineteenth-Century Europe. Baltimore and London: The Johns Hopkins University Press.

- (1999). Figural realism: Studies in the Mimesis Effect. Baltimore and London: The Johns Hopkins University Press.

Zeleňák, Eugen (2009). «Exploring Holism in Frank Ankersmit's Historical Representation». Rethinking History 13.3 (September: 357-369). 